\title{
Green Tea (Camellia sinensis) Extract Reduces Peptic Ulcer Induced by Helicobacter pylori in Sprague Dawley Rats
}

(Ekstrak Teh Hijau (Camellia sinensis) Mengurangkan Ulser Peptik yang Diaruh oleh Helicobacter pylori pada Tikus Sprague Dawley)

\author{
Marhanis Salihah Omar, Nur Nadiana Adnan, Endang Kumolosasi*, Norazrina Azmi, Noor Safwah \\ DAMANHURI \& FHATAHEYA BUANG
}

\begin{abstract}
The study was conducted to evaluate the anti-peptic ulcer activity of ethanol extract of Camellia sinensis (green tea) induced by Helicobacter pylori in Sprague Dawley rats. The standard regimen of anti-peptic ulcer agents, clarithromycin $30 \mathrm{mg} / \mathrm{kg}$, amoxicillin $30 \mathrm{mg} / \mathrm{kg}$ and esomeprazole $3 \mathrm{mg} / \mathrm{kg}$ used as the positive control. The rats divided into 6 groups $(n=6)$, normal control, vehicle control ( $2 \%$ of tragacanth suspension), positive control for preventive and treatment groups, preventive and treatment groups were given $50 \mathrm{mg} / \mathrm{kg}$ orally of green tea extract for 14 days before and after inoculation (as prevention and treatment, respectively) with $5 \times 10^{8} \mathrm{CFU} / \mathrm{mL} \mathrm{H}$. pylori suspension orally twice daily for 7 days. Anti-peptic ulcer activity was evaluated based on the $\mathrm{pH}$ of gastric juice, ulcer score and body weight of rats. The results demonstrated that the use of green tea for prevention or treatment showed a significant difference $(p<0.001)$ in reducing the $p H$ of gastric juice $3.88 \pm 0.09$ and $5.74 \pm 0.08$, respectively, compared to vehicle control $5.85 \pm 0.12$. Meanwhile, vehicle control rats had high significantly reduced body weight when compared with all groups treated. The preventive and the treatment groups showed significantly reduce in ulcer score to $0.50 \pm 0.18(p<0.01)$ and 0.83 \pm 0.10 ( $p<0.05$ ), respectively, compared to vehicle control $1.50 \pm 0.22$. Meanwhile, it was comparable to the positive control. In conclusion, $\mathrm{H}$. pylori suspension $5 \times 10^{8} \mathrm{CFU} / \mathrm{mL}$ given orally twice daily for seven days able to induce ulcer in Sprague Dawley rats, and the green tea extract $50 \mathrm{mg} / \mathrm{kg}$ was comparable to the standard regimen as anti-peptic ulcer agent.
\end{abstract}

Keywords: Anti-peptic ulcer; Camellia sinensis; green tea extract; Helicobacter pylori; ulcer score

\section{ABSTRAK}

Kajian ini dijalankan untuk menilai aktiviti anti-ulser peptik ekstrak etanol Camellia sinensis (teh hijau) yang diaruhkan oleh Helicobacter pylori pada tikus Sprague Dawley. Regimen piawai agen anti-ulser peptik, klaritromisin $30 \mathrm{mg} / \mathrm{kg}$, amoksisilin $30 \mathrm{mg} / \mathrm{kg}$ dan esomeprazol $3 \mathrm{mg} / \mathrm{kg}$ digunakan sebagai kawalan positif. Tikus dibahagikan kepada 6 kumpulan $(n=6)$, kawalan normal, kawalan pembawa (2\% suspensi tragacanth), kawalan positif untuk kumpulan pencegahan dan rawatan, kumpulan pencegahan dan rawatan yang diberikan ekstrak teh hijau $50 \mathrm{mg} / \mathrm{kg}$ secara oral selama 14 hari sebelum atau selepas inokulasi (sebagai kumpulan pencegahan dan rawatan) berserta dengan pemberian ampaian $5 \times 10^{8} \mathrm{CFU} / \mathrm{mL} \mathrm{H}$. pylori secara oral sebanyak dua kali sehari selama 7 hari. Aktiviti anti-ulser peptik dinilai berdasarkan pH jus gastrik, skor ulser dan berat badan tikus. Keputusan menunjukkan bahawa penggunaan teh hijau untuk pencegahan atau rawatan menunjukkan perbezaan yang signifikan $(p<0.001)$ dalam mengurangkan $p H$ jus gastrik $3.88 \pm 0.09$ dan $5.74 \pm 0.08$, setiap satu, berbanding dengan kawalan pembawa $5.85 \pm 0.12$. Sementara itu, terdapat penurunan berat badan yang ketara dalam tikus kawalan pembawa apabila dibandingkan dengan semua kumpulan yang dirawat. Kumpulan pencegahan dan rawatan menunjukkan penurunan skor ulser menjadi $0.50 \pm$ $0.18(p<0.01)$ dan $0.83 \pm 0.10(p<0.05)$, berbanding kawalan pembawa $1.50 \pm 0.22$. Ia adalah setanding dengan kawalan positif. Sebagai kesimpulan, pemberian ampaian H. pylori $5 \times 10^{8} \mathrm{CFU} / \mathrm{mL}$ diberikan secara oral dua kali setiap hari selama tujuh hari dapat menyebabkan ulser pada tikus Sprague Dawley dan ekstrak teh hijau $50 \mathrm{mg} / \mathrm{kg}$ adalah setanding dengan regimen piawai sebagai agen anti-ulser peptik.

Kata kunci: Anti-ulser peptik; Camellia sinensis; ekstrak teh hijau; Helicobacter pylori; skor ulser 


\section{INTRODUCTION}

Peptic ulcer diseases comprise heterogeneous disorder which manifests as a break in the lining of the gastrointestinal mucosa bathed by acid and pepsin. Generally, this happens due to the imbalance between gastric aggressive and mucosal defensive factors. Based on the site of the attack, peptic ulcer disease embraces both gastric and duodenal ulcer. The etiology of peptic ulcer is influenced by any aggressive factor and protective factors such as acid-pepsin secretion, parietal cell, mucus secretion, mucosal barrier, cellular regeneration, and endogenous protective agent prostaglandin and epidermal growth factor (Adinortey et al. 2013). Other factors are contributing to this disease, such as bad dietary habit, excessive intake of a non-steroidal anti-inflammatory agent, hereditary stress predisposition, and Helicobacter pylori infection.

Helicobacter pylori, a Gram-negative and helical rod causes chronic gastritis and peptic ulcer and essential factor in gastric cancer occurrence. Epidemiological studies showed a strong correlation between $H$. pylori infections and peptic ulcer (Elseweidy et al. 2010). $H$. pylori eradication accelerates peptic ulcer healing and reduces the recurrence of gastric ulcer. Nowadays, triple therapies consisting of two antibiotics, and a proton pump inhibitor show high eradication rates. Unfortunately, H. pylori rapidly acquire resistance to some antibiotic through certain gene mutation mechanism. Soon, antibiotic resistance will be the most significant obstacles in the treatment of $H$. pylori. Besides, several pharmaceutical drugs recommended for peptic ulcer management provoke many adverse effects; abdominal discomfort, diarrhoea, and nausea. Because of that, a new alternative regimen with highly effective and safe is required for the treatment of $H$. pylori infection. Recently, there have been growing interests in alternative therapies, especially from plant sources, because of easy accessibility and affordability. It had been reported that various medicinal plants extracts have antibacterial activity. Thus, this plant may contain a new antibacterial agent that has potential as a new therapeutic agent.

Tea is considered one of the most popular beverages, especially in China and Japan. Green tea (Camellia sinensis) is prepared from the withered leaves are steamed and then dried relatively rapid after plucking process to minimize chemical and enzyme reaction polyphenol oxidase (PPO). The green tea (GT) contains catechin included in polyphenol group which susceptible to be oxidized by PPO enzyme. The major polyphenolic compound in tea is the flavan-3-ols called catechins which include epicatechin (EC), epigallocatechin (EGC), epicatechin gallate (ECG), epigallocatechingallate (EGCG), gallocatechin (GC), and gallocatechin gallate
(GCG). Due to the possession of phenolic hydroxyl group attached to flavon-3-ol structure has been associated with the ability of tea to scavenge free radical, thereby attracting tremendous research interest (Amić et al. 2003). It has been reported that tea catechins have antibacterial activity against various foodborne pathogenic bacteria (Mabe et al. 1999). Ultimately, the previous study has shown that polyphenol group compound able to inhibit Vac-A, which play an essential role for $H$. pylori in its survival other than urease enzyme in the stomach (Tombola et al. 2003). Thus, it seems reasonable to explore the possibility of using GT for the eradication of $H$. pylori. It is such a benefit to use GT as an agent for therapeutic or prevention deserves consideration.

\section{MATERIAL AND METHODS}

\section{PLANT MATERIALS}

The GT leaves were purchased from a food and beverage department in Kuala Lumpur, Malaysia with the brand Ujinotsuyu and the name of the product is Aoyanagi Green. The GT was in loose tea leaves form and the type of GT used was Bancha.

\section{BACTERIA}

H. pylori were maintained on columbia blood agar (Merck KGaA, Darmstadt, Germany) supplemented with 10\% lake horse blood (Thermo Fisher Scientific USA) and H. pylori selective supplement (DENT) (Oxoid Limited, Thermo Fisher Scientific) at $37^{\circ} \mathrm{C}$ (atmosphere: $5 \% \mathrm{CO}_{2}$ or $95 \%$ air) for up to 5 to 7 days. The bacteria were confirmed as $H$. pylori strain by gram staining, oxidase, catalase and urease positive test.

\section{CHEMICAL AND MEDIA}

The chemicals and media used in this study were ethanol 100\% (Merck Germany), tragacanth powder, clarithromycin $500 \mathrm{mg}$ tablet (Abott Laboratories, Malaysia), amoxycillin trihydrate $500 \mathrm{mg}$ capsule (CCM, Malaysia), esomeprazole $40 \mathrm{mg}$ tablet (AstraZeneca, Malaysia), laked Horse blood and $H$. pylori selective supplement (BUMI-PHARMA, Malaysia), horse blood serum (Thermo Fischer Scientific, Malaysia), muellerhinton broth (Difco Laboratories, Dtroit,Mich) and distilled water.

\section{APPARATUS AND INSTRUMENTS}

The apparatus and instruments used in this study were oral gavages, micropipette $100-1000 \mu \mathrm{L}$ (Socorex, Switzerland), $\mathrm{CO}_{2}$ incubator (Thermo Fischer Scientific, USA), rotary evaporator (BUCHI, Switzerland), ultrasonicator (Branson USA), UV-Visible spectrophotometer (Shimadzu, Japan), 
electronic balance (Segatec, Malaysia), laminar flow cabinet class II (CLYDEC-APAC, Australia), autoclave (FC BIOS, Malaysia), freeze dryer (Thermo fisher scientific, Malaysia) and $\mathrm{pH}$ meter.

\section{ANIMAL}

A total of 40 adult male healthy Sprague Dawley rats weighing between 150 - 250 g were obtained and purchased from Laboratory Animal Resources Unit, Universiti Kebangsaan Malaysia. All rats were given 7 days of acclimation period for adaptation. The rats were placed at standard controlled room $\left( \pm 25^{\circ} \mathrm{C}\right.$ and cycle of 12-h light and 12-h dark). Rats were supplied with standard laboratory food pellets and water ad libitum. The experimental procedure used in this study was approved by the Universiti Kebangsaan Malaysia Animal Ethics Committee (UKMAEC) with approval number FF/2015/ ENDANG/20-MAY/6881-MAY-2015-JAN 2016.

\section{Methods}

\section{PREPARATION AND STANDARDIZATION OF GT EXTRACTS}

The product was ground into coarse powder using a mechanical grinder which was then macerated by soaking it in $80 \%$ ethanol at a ratio of $1: 5 \mathrm{w} / \mathrm{v}$ for three days at room temperature $\left(30^{\circ} \mathrm{C}\right)$ with occasional shaking. After the extraction was completed, filtration was carried out and the filtrates were concentrated using a rotatory evaporator at $40{ }^{\circ} \mathrm{C}$ to yield a crude extract of GT. Standardization of GT extract was performed using kaempferol and quercetin as standards. Chromatographic column was performed using a reverse phase HPLC (Waters, Milford, MA, USA) equipped with Water Breeze system. XBridgeTM Column C50 $5 \mu \mathrm{m}(4.60 \times 250 \mathrm{~mm}$ particle diameter, $5 \mu \mathrm{m}$; Thermo Scientific, USA) (Waters, Ireland) was used for separation. The mobile phase for kaempferol and quercetin consisted of $0.05 \%$ orthophosphoric acid and acetonitrile at a ratio 50:50 (v/v) and methanol: acetonitrile: deionized water at a ratio 60:20:20 v/v/v, respectively. The flow rate of the mobile phase was set at $0.3 \mathrm{~mL} / \mathrm{min}$ with $20 \mu \mathrm{L}$ of injection volume. Kaempferol was detected at $360 \mathrm{~nm}$ and quercetin at $262 \mathrm{~nm}$. Validation of the HPLC method was carried out by determining the linearity, precision, limits of quantification and detection (Azmi et al. 2018).

\section{DOSE PREPARATION OF GT AND DRUGS}

Camellia sinensis, amoxicillin, clarithromycin, and esomeprazole were suspended in tragacanth $2 \%$. The GT extract dose used was $50 \mathrm{mg} / \mathrm{kg}$ and for drugs doses such as clarithromycin, amoxicillin, and esomeprazole were 30,30 , and $3 \mathrm{mg} / \mathrm{kg}$, respectively (Adinortey et al. 2013).
All the samples were administered through oral gavage method and weights of rat were measured throughout the experiment.

\section{PREPARATION OF BACTERIAL INOCULUMS ON BLOOD AGAR MEDIUM}

The H. pylori inoculums on blood agar medium was performed according to Xu et al. (2010). Briefly a number of viable isolated colonies of $H$. pylori culture were inoculated on blood agar medium incubated in $\mathrm{CO}_{2}$ incubator with humidity tray at $37^{\circ} \mathrm{C}$ and $5 \% \mathrm{CO}_{2}$ for 72 to $92 \mathrm{~h}$. However, H. pylori was passaged every 3 to 5 days.

\section{PREPARATION OF BACTERIAL INOCULUMS SUSPENSION}

The H. pylori suspension were prepared from bacterial inoculums above to the universal bottles containing Mueller-hinton broth, $10 \%$ horse serum and $0.1 \%$ yeast extract liquid medium. The suspension was incubated for $24 \mathrm{~h}$ at $37{ }^{\circ} \mathrm{C}$ in $5 \% \mathrm{CO}_{2}$ Enumeration of $\mathrm{H}$. pylori suspension was done using UV-Vis spectrophotometer reading at $450 \mathrm{~nm}$ until the final concentration of $H$. pylori was $10^{8} \mathrm{CFU} / \mathrm{mL}$ (Shahamat et al. 1991; Xia et al. 1993).

\section{EXPERIMENTAL ANTI-PEPTIC ULCER}

The rats were divided into 6 groups $(n=6)$ as normal control group, vehicle control group, positive control of prevention and treatment groups, prevention and treatment groups (Burkitt et al. 2017). In the prevention and treatment experiments, vehicle control rats were given $1 \mathrm{~mL} /$ rat of tragacanth $2 \%$ suspension, positive control groups were given clarithromycin $(30 \mathrm{mg} / \mathrm{kg})$, amoxicillin $(30 \mathrm{mg} / \mathrm{kg})$ and esomeprazole $(3 \mathrm{mg} / \mathrm{kg})$ and the prevention and treatment groups were given GT extract $50 \mathrm{mg} / \mathrm{kg}$ orally once a day for 14 days before and after, respectively, being inoculated orally with $1 \mathrm{~mL} / \mathrm{rat}$ of $H$. pylori suspension $\left(5 \times 10^{8} \mathrm{CFU} / \mathrm{mL}\right)$ twice daily at an interval for $4 \mathrm{~h}$ for 7 days. At day- 1 after the last day of inoculation for the prevention group and the last day of treatment for the treatment group, the rats were all sacrificed by cervical dislocation after anaesthesia and rapidly excised the stomach. Gastric content was collected to determine $\mathrm{pH}$ of gastric juice. Stomach was then opened along greater curvature washed with saline to record the ulcer score.

\section{ANTI-PEPTIC ULCER ACTIVITY EVALUATION}

Macroscopic examination carried out based on grading $0-5$ scale. The following scoring in Table 1 was used to evaluate the ulcer as well as the severity of gastric lesion (Mahmood et al. 2009; Sonwjaya et al. 2016). 
TABLE 1. Ulcer score and its description

\begin{tabular}{ll}
\hline \multicolumn{1}{c}{ Ulcer score } & \multicolumn{1}{c}{ Description } \\
\hline 0 & No lesion (normal stomach) \\
0.5 & hyperaemia (red coloration)/hemorrhagic spot \\
1 & $1-5$ small ulcer $(<1 \mathrm{~mm})$ with/without hemorrhagic spot, \\
2 & $1-5$ small ulcer $(1 \mathrm{~mm}-2 \mathrm{~mm})$ with/without hemorrhagic spot \\
3 & more than five small lesions or one intermediate lesion $(3 \mathrm{~mm}-4 \mathrm{~mm})$ with/without hemorrhagic spot \\
4 & 2 or more intermediate lesion or one gross lesion $(4 \mathrm{~mm})$ with/without hemorrhagic spot \\
5 & perforated ulcer with/without hemorrhagic spot \\
\hline
\end{tabular}

Data were analyzed statistically by one-way analysis of variance (ANOVA) followed by Dunnett's post hoc test using GraphPad Prism 5 . All the data were expressed as mean $\pm \operatorname{SEM}(\mathrm{n}=6)$. $p$ value $<0.05$ is considered as statistical significant.

\section{RESULTS}

\section{STANDARDIZATION OF GT EXTRACTS}

Validation of the HPLC method was carried out and the kaempferol and quercetin calibration curves plotted were linear within the concentration range of 13 to $200 \mu \mathrm{g} /$ $\mathrm{mL}$ and 31 to $500 \mu \mathrm{g} / \mathrm{mL}$, respectively, with a correlation coefficient $\left(\mathrm{r}^{2}\right)$ of 0.9878 and 0.9961 also, respectively. The retention time of kaempferol in the GT extract was 14.280 min whilst for kaempferol standard was 14.750 min. Furthermore, the retention time for quercetin in the GT extract and its standard were 2.518 and $2.738 \mathrm{~min}$, respectively. The concentration of kaempferol in GT extract was $3.10 \mathrm{mg} / \mathrm{g}$ and quercetin was $0.8 \mathrm{mg} / \mathrm{g}$.

\section{ANTI-PEPTIC ULCER OF GT EXTRACT}

Table 2 shows that the treatment and preventive groups using GT extract $50 \mathrm{mg} / \mathrm{kg}$ had significant different value in lowering $\mathrm{pH}$ of gastric juice $(\mathrm{p}<0.001)$ when compared to vehicle control. The capacity to decrease the $\mathrm{pH}$ of gastric juice in prevention and treatment groups with $\mathrm{pH}$ of $3.88 \pm 0.09(\mathrm{p}<0.001)$ and $5.74 \pm 0.08(\mathrm{p}<0.001)$, respectively, showed lower than their own positive controls.

TABLE 2. Anti-peptic ulcer effect of Camellia sinensis induced by H. pylori in Sprague Dawley rats in experimental anti-peptic ulcer

\begin{tabular}{lccc}
\hline \multicolumn{1}{c}{ Experimental } & pH of gastric juice & Ulcer score & Body weight $(\mathrm{g})$ \\
\hline Healthy (normal control) rats & $2.36 \pm 0.17^{* * *}$ & 0 & $253.32 \pm 5.85^{* * *}$ \\
Vehicle control group & $5.85 \pm 0.12$ & $1.50 \pm 0.22$ & $149.66 \pm 8.32$ \\
$\begin{array}{l}\text { Positive control of preventive } \\
\text { group }\end{array}$ & $2.65 \pm 0.24^{* * *}$ & $0.58 \pm 0.20^{* *}$ & $253.83 \pm 16.48^{* * *}$ \\
Preventive group with GT extract & $3.88 \pm 0.09^{* * *}$ & $0.50 \pm 0.18^{* *}$ & $249.67 \pm 6.73^{* * *}$ \\
Positive control of treatment group & $4.31 \pm 0.21^{* * *}$ & $0.66 \pm 0.16^{*}$ & $229.66 \pm 0.03^{* * *}$ \\
Treatment group with GT extract & $5.74 \pm 0.08^{* * *}$ & $0.83 \pm 0.10^{*}$ & $197.00 \pm 13.35^{* * *}$ \\
\hline
\end{tabular}

Normal control was healthy rats without inoculation neither treatment, vehicle control was inoculated with $H$. pylori without prevention or treatment. Positive control of prevention and treatment groups were given the standard regimen $(30 \mathrm{mg} / \mathrm{kg}$ clarithromycin, $30 \mathrm{mg} / \mathrm{kg}$ amoxicillin, $3 \mathrm{mg} / \mathrm{kg}$ esomeprazole) before and after inoculated with H. pylori, respectively. *, **, $* * *$ significant with $\mathrm{p}$ value $<0.05,<0.01$ and $<0.001$, respectively, compared with vehicle control. Values were expressed in mean \pm SEM. $\mathrm{N}=6$ 
In term of ulcer score evaluation, the anti-peptic ulcer effect of GT extract in preventive group and treatment group had significant different ulcer score $0.50 \pm 0.18$ $(\mathrm{p}<0.01)$ and $0.83 \pm 0.10(\mathrm{p}<0.05)$, respectively, compared to negative control that produce more ulcer $1.50 \pm 0.22$. Contrary, these values were not significant different or comparable with their own positive control (Table 1, Figures 1 \& 2).
A

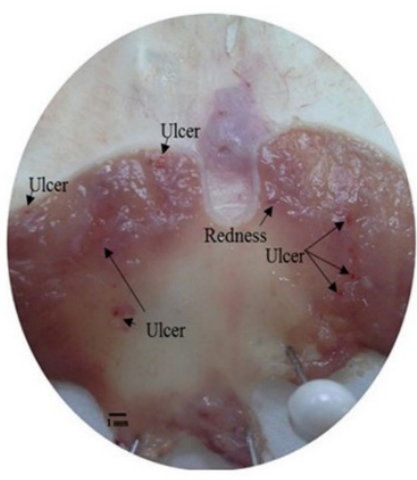

Avbw: $149.66 \pm 8.32$

AvpH: $5.85 \pm 0.12$

Avul score: $1.50 \pm 0.22$
B

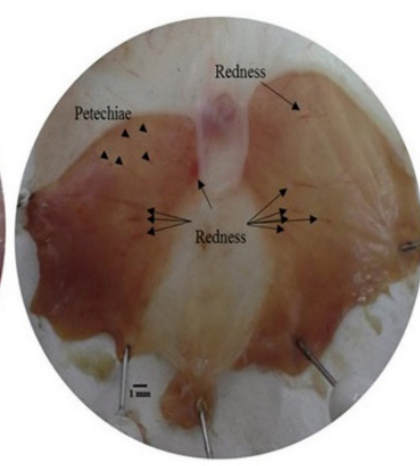

Avbw: $253.83 \pm 16.48^{* *}$ AvpH: $2.56 \pm 0.24^{* * *}$
C

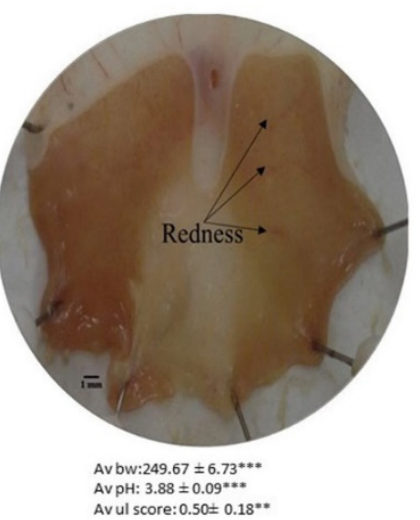

FIGURE 1. Representative picture of vehicle control group, positive control preventive group and preventive group with GT extract. Av bw: average of body weight; Av pH: average $\mathrm{pH}$ of gastric juice; $\mathrm{Av} \mathrm{uL}$ score: average of ulcer score. All groups were inoculated with $H$. pylori $5 \times 10^{8} \mathrm{CFU} / \mathrm{mL}$ twice daily for 7 days after 14 days treatment (a) Vehicle control, (b) positive control of preventive group with standard regimen (30 $\mathrm{mg} / \mathrm{kg}$ clarithromycin, $30 \mathrm{mg} / \mathrm{kg}$ amoxicillin, $3 \mathrm{mg} / \mathrm{kg}$ esomeprazole), and (c) preventive group with $50 \mathrm{mg} / \mathrm{kg} \mathrm{GT}$ extract. *, **, *** significant with $\mathrm{p}$ value $<0.05,<0.01$ and $<0.001$ respectively compared with vehicle control. Values mean \pm SEM. $\mathrm{N}=6$

A

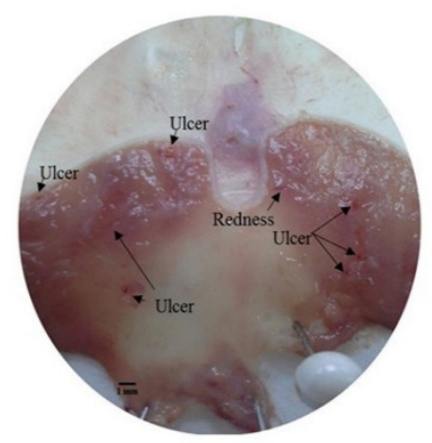

Av bw: $149.66 \pm 8.32$ Av pH: $5.85 \pm 0.12$
B

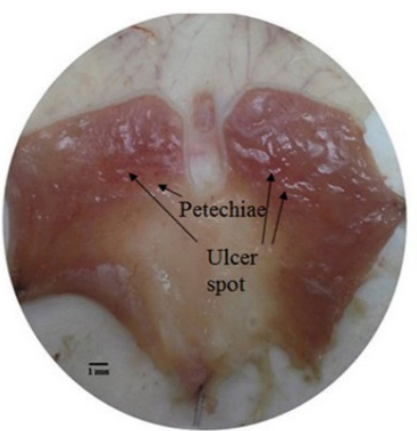

Av bw: $229.66 \pm 0.03^{* * *}$ Av pH: $4.31 \pm 0.21 * * *$
C

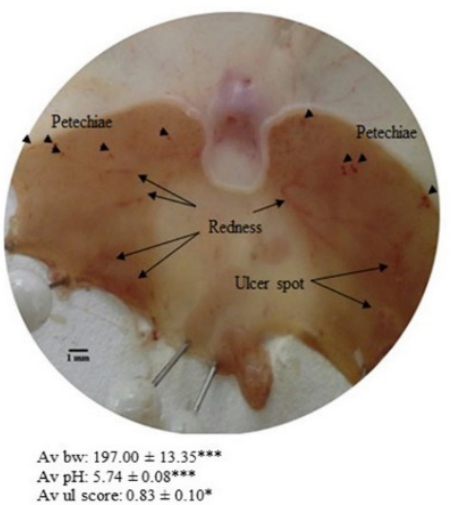

FIGURE 2. Representative picture of vehicle control group, positive control treatment group and treatment group with GT extract. Av bw: average of body weight; $\mathrm{Av} \mathrm{pH}$ : average $\mathrm{pH}$ of gastric juice; Av uL score: average of ulcer score. All groups were inoculated with H. pylori $5 \times 10^{8}$ $\mathrm{CFU} / \mathrm{mL}$ twice daily for 7 days before 14 days treatment (a) Vehicle control, (b) positive control of treatment group with standard regimen $(30 \mathrm{mg} / \mathrm{kg}$ clarithromycin, $30 \mathrm{mg} / \mathrm{kg}$ amoxicillin, 3 $\mathrm{mg} / \mathrm{kg}$ esomeprazole), and (c) treatment group with $50 \mathrm{mg} / \mathrm{kg}$ GT extract. *,**,***: significant with $\mathrm{p}$ value $<0.05,<0.01$ and $<0.001$ respectively compared with vehicle control. ${ }^{\text {ns: }}$ non significant compared with negative control. Values mean \pm SEM. $\mathrm{N}=6$ 
Moreover, the vehicle control group showed decrease in body weight with high significant difference with value $149.66 \pm 8.32(\mathrm{p}<0.001)$ compared with all groups in the study (Table 1). From the three parameters determined in this study, it was found that Camellia sinensis extract at dose $50 \mathrm{mg} / \mathrm{kg}$ had a potency to decrease the $\mathrm{pH}$ of gastric juice, to reduce the ulcer score and to increase the body weight of rats.

\section{DISCUSSION}

Human H. pylori have difficulty to infect and produce peptic ulcer in rodent as an animal model. In 1996, however, Hirayama et al. (1996) reported that a Mongolian gerbil (MG) is a good model of human $H$. pylori infection, with the bacteria detectable throughout a 12-month study period with the results of chronic active gastritis, peptic ulcers resemble lesions apparent in man (Hirayama et al. 1996). Moreover, Werawatganon (2014) established a simple rat model of chronic $H$. pylori infection using Sprague-Dawley rats to develop chronic peptic ulcer. Our preliminary study was performed subjected to Werawatganon (2014) with a small modification. The results of our study showed that $H$. pylori suspended in Muller-Hinton broth $5 \times 10^{8} \mathrm{CFU} / \mathrm{mL}$ administered orally twice daily for 7 days able to induce peptic ulcer with ulcer score in range of $1.50 \pm 0.22$ to $3.00 \pm 1.00$ in Sprague Dawley rats and the effective dose of Camellia sinensis extract was $50 \mathrm{mg} / \mathrm{kg}$. The number of $H$. pylori and the treatment of GT extract were used for anti-peptic ulcer experiment.

In this experimental anti-peptic ulcer effect of Camellia sinensis, $50 \mathrm{mg} / \mathrm{kg}$ of plant extract been implemented to be used in rats based on the preliminary test result. This dose determined from the preliminary study and showed the anti-peptic ulcer activity. Parameters that been used to evaluate anti-peptic ulcer activity were $\mathrm{pH}$ of gastric juice, ulcer score, and the average weight of rats. These parameters were presented in the previous study done by Nair et al. (2010).

In our study, the $\mathrm{pH}$ of gastric juice in preventive and treatment groups using Camellia sinensis extract is lower significantly difference compared to the vehicle control but they showed higher $\mathrm{pH}$ compared with their positive control. It approved that positive control more effective in maintaining the $\mathrm{pH}$ of gastric juice to normal range compared to the test group. It indicated that plant extract had anti-peptic ulcer effects but not comparable with standard regimen $(30 \mathrm{mg} / \mathrm{kg}$ clarithromycin, $30 \mathrm{mg} /$ $\mathrm{kg}$ amoxicillin, and $3 \mathrm{mg} / \mathrm{kg}$ esomeprazole) in decreasing $\mathrm{pH}$. Esomeprazole, a drug that targets specifically to inhibit $\mathrm{H}(+) / \mathrm{K}(+)$-exchanging ATPase), which is a gated channel that regulates gastric acid secretion and $\mathrm{pH}$ of gastric juice. To maintain the normal $\mathrm{pH}$ of gastric juice when infected by $H$. pylori, the GT extract was not strong enough compared with the triple standard regimen with a specific mechanism of action. Based on the previous study carried out by Prabha et al. (2011), Musa sapientum-treated animal causes an increase in $\mathrm{pH}$ of gastric juice because of the ability of Musa sapientum extract inhibit the HCI (Prabha et al. 2011). However, this study showed that Camellia sinensis extract had a lower ability to maintain and regulate the $\mathrm{pH}$ of gastric juice compared to standard regimen (positive control).

Tea is consumed in three basic forms: GT, black tea (BT), and oolong tea (OT). Although BT accounts for $80 \%$ of the total tea consumption, studies on the pharmacological properties of BT are scarce. The tea polyphenols, especially the catechins are primarily responsible for the curing property of GT, however, during the production of $\mathrm{BT}$, a significant part of the catechins is converted to the theaflavins (TF) (comprising of theaflavin-3-gallate, theaflavin-3'-gallate, and theaflavin3,3'-digallate) and thearubigins by a polyphenol oxidase (Adhikary at al. 2011). Study by Adhikary at al. (2011) also showed that the biochemical transformation of GT into BT did not hamper the ulcer healing property, and also established TF as the active antiulcerogenic principle of BT. Both BT and TF were found to exert their action by augmenting mucosal antioxidant defense, protecting mucin and increasing the cyclooxygenase (COX-) derived prostaglandin E (PGE) synthesis in male Swiss albino mice was ulcer-induced by indomethacin. Their results are consistent with the anti-inflammatory property of TF. Based on the available evidence, the therapeutic effect of these BT and FT samples could be related to their antioxidant, mucin-protecting, and PGE-enhancing properties (Adhikary at al. 2011).

Our study has used $H$. pylori infection as an ulcer inducer in Sprague Dawley Rats treated with ethanol extract of Camellia sinensis (GT). The chemical contents of GT have been established such as catechin included in polyphenol group which susceptible to be oxidized by polyphenol oxidase (PPO) enzyme. The major polyphenolic compound in the GT is the flavan-3-ols called catechins which include epicatechin (EC), epigallocatechin (EGC), epicatechin gallate (ECG), epigallocatechingallate (EGCG), gallocatechin (GC) and gallocatechin gallate (GCG). Due to the possession of phenolic hydroxyl group attached to flavon-3-ol structure has been associated with the ability of GT to scavenge free radical, thereby attracting tremendous research interest (Amić et al. 2003). It has been reported that GT catechins have antibacterial activity against various foodborne pathogenic bacteria (Mabe et al. 1999). Ultimately, the previous study has shown that polyphenol group compound able to inhibit $\mathrm{Vac}-\mathrm{A}$, which play an essential role for $H$. pylori in its survival other than urease enzyme in the stomach (Tombola et al. 2003). 
Furthermore, it has been suggested that $\operatorname{VacA}$ is a significant virulence factor of $H$. pylori by causing cell vacuolation and tissue damage by forming anion-selective, urea permeable channels in plasma and endosomal membranes. It has been activated by exposure to acid or basic pH (Palframan et al. 2012). Furthermore, it has been reported that $\mathrm{VacA}$ inhibitor such as phloretin had structural similarities with polyphenol such as flavonol, flavones, and isoflavone (Tombola et al. 2003). Besides, urease activity facilitates colonization either by producing ammonia which protects the acid sensitive bacteria in their transit across the gastric lumen to their final location below gastric mucus. The results of this study confirm that the urease activity not merely to modulate the $\mathrm{pH}$ but is also essential for colonization in vivo. The hypothesis state that without urease enzyme, the $H$. pylori cannot be able to survive in $\mathrm{pH}$ of gastric because $H$. pylori can only colonize and proliferate in alkaline gastric (Dunne et al. 2014).

The anti-peptic ulcer activity further evaluated based on the ulcer score. The results showed that preventive and treatment groups had significant differences in ulcer score values compared to vehicle control. Meanwhile, both groups showed comparable in ulcer score values with their positive control. It was demonstrated that Camellia sinensis extract is able to reduce the ulcer score at the same effectiveness with the standard regimen (clarithromycin, amoxicillin, and esomeprazole). The FDA already approved this standard regimen for their efficacy in treating peptic ulcer induced by H. pylori. The resistance of $H$. pylori towards antibiotics is worrying especially against metronidazole, which is the most common pattern of resistance worldwide (Savoldi et al. 2018). It had been reported that the resistance to other antibiotics had been risen because of gene mutation at certain protein will cause decrease drug binding and lead ineffectiveness of treatment (Mégraud et al. 2012). Hence it seems a good possibility for active substances in plants, especially GT leaves as an alternative for eradicating $H$. pylori and to overcome the possibility of resistant $H$. pylori against standard regimen.

There was a significant decrease in the average body weight of rats in the vehicle control compared to all groups. Treatment with Camellia sinensis extract had increased significantly in average body weight of rats. The vehicle control rats consistently decreased in body weight throughout the experiment. This result showed that Camellia sinensis extract could stabilize the body weight compared to negative control rats. Overall, Camellia sinensis extract had anti-peptic ulcer activity comparable with the standard regimen. GT itself as a nutraceutical but it is possible to isolate the active compounds as anti- $H$. pylori infection.

\section{CONCLUSION}

From the results of our study, it can be concluded that $H$. pylori suspended in Muller-hinton broth $5 \times 10^{8} \mathrm{CFU} / \mathrm{mL}$ administrated orally twice daily for 7 days able to induce peptic ulcer with ulcer score in range of $1.50 \pm 0.22$ to $3.00 \pm 1.00$ in Sprague Dawley rats. Furthermore, the Camellia sinensis extract was able to reduce the ulcer score with effectiveness comparable with standard regimen (clarithromycin, amoxicillin, and esomeprazole), but this extract had an ability to decrease the $\mathrm{pH}$ of gastric juice but is not as strong as standard regimen. It is seemed a good possibility for active substances in plants, especially GT leaves as an alternative to treat $H$. pylori infection and to overcome the possibility of resistant $H$. pylori against standard regimen with further study.

\section{ACKNOWLEDGEMENTS}

This project has been funded by Universiti Kebangsaan Malaysia with grant number GGPM-2013-094. Bacteria strain used in this study was kindly supplied by Assoc. Prof. Dr Alfizah Hanafiah from the Department of Medical Microbiology and Immunology, UKM Cheras, Malaysia. The experimental procedure used in this study was approved by the Universiti Kebangsaan Malaysia Animal Ethics Committee (UKMAEC) with approval number FF/2015/ENDANG/20-MAY/6881-MAY-2015JAN 2016. EK conceptualized the study hypothesis and coordinated the research activities, NNA and FB performed the experiments, MSO and NA carried out statistical data analysis. The manuscript was written by NNA and NSD and reviewed by EK. All authors have read and approved the manuscript. The authors declare no competing interests.

\section{REFERENCES}

Adhikary, B., Yadav, S.K., Roy, K., Bandyopadhyay, S.K. \& Chattopadhyay, S. 2011. Black Tea and theaflavins assist healing of indomethacin-induced gastric ulceration in mice by antioxidative action. Evidence-Based Complementary and Alternative Medicine 2011: Article ID. 546560.

Adinortey, M.B., Ansah, C., Galyuon, I. \& Nyarko, A. 2013. In vivo models used for evaluation of potential antigastroduodenal ulcer agents. Ulcers 13(2): 1-13.

Amić, D., Davidović-Amić, D., Bešlo, D. \& Trinajstić, N. 2003. Structure-radical scavenging activity relationships of flavonoids. Croatica Chemica Acta 76(1): 55-61.

Azmi, N., Chee, S.H., Mohd Fauzi, N., Jasamai, M. \& Kumolosasi, E. 2018. Viability and apoptotic effects of green tea (Camellia sinensis) methanol extract on human leukemic cell lines. Acta Poloniae Pharmaceutica 75(1): 51-58.

Burkitt, M.D., Duckworth, C.A., Jonathan, M., Williams, J.M. \& Pritchard, D.M. 2017. Helicobacter pylori-induced gastric pathology: Insights from in vivo and ex vivo models. Disease Models \& Mechanisms 10: 89-104. 
Dunne, C., Dolan, B. \& Clyne, M. 2014. Factors that mediate colonization of the human stomach by Helicobacter pylori. World Journal of Gastroenterology 20(19): 5610-5624.

Elseweidy, M.M., Taha, M.M., Younis, N.N., Ibrahim, K.S., Hamouda, H.A., Eldosouky, M.A. \& Soliman, H. 2010. Gastritis induced by Helicobacter pylori infection in experimental rats. Digestive Diseases and Sciences 55(10): 2770-2777.

Hirayama, F., Takagi, S., Yokoyama, Y., Iwao, E. \& Ikeda, Y. 1996. Establishment of gastric Helicobacter pylori infection in mongolian gerbils. The Journal of Gastroenterology 31(9): 24-28.

Mabe, K., Yamada, M., Oguni, I. \& Takahashi, T. 1999. In vitro and in vivo activities of tea catechins against Helicobacter pylori. Antimicrobial Agents and Chemotherapy 43(7): 1788-1791.

Mahmood, A.A., Mariod, A.A., Al-Bayaty, F. \& Abdel-Wahab, S.I. 2009. Antiulcerogenic activity of Gynura procumbens leaf extract against experimentally-induced gastric lesions in rats. Journal of. Medicinal Plants Research 4(8): 685-691.

Mégraud, F. 2012. The challenge of Helicobacter pylori resistance to antibiotics: The comeback of bismuth-based quadruple therapy. Therapeutic Advances in Gastroenterology 5(2): 103-109.

Nair, V., Arjuman, A., Gopalakrishna, H.N., Dorababu, P., Mirshad, P.V., Bhargavan, D. \& Chatterji, D. 2010. Evaluation of the anti-ulcer activity of NR-ANX-C (a polyherbal formulation) in aspirin \& pyloric ligature induced gastric ulcers in albino rats. The Indian Journal of Medical Research 132: $218-223$

Palframan, S.L., Kwok, T. \& Gabriel, K. 2012. Vacuolating cytotoxin A (VacA), a key toxin for Helicobacter pylori pathogenesis. Frontiers in Cellular and Infection Microbiology 2(92): 1-9.

Prabha, P., Karpagam, T., Badrinarayanan, V. \& Packiavathy, A.S.C. 2011. Indigenous anti-ulcer activity of Musa sapientum on peptic ulcer. Pharmacognosy Research 3(4): 232-238.

Savoldi, A., Carrara, E., Graham, D.Y., Conti, M. \& Tacconelli, E. 2018. Prevalence of antibiotic resistance in Helicobacter pylori: A systematic review and meta-analysis in world health organization regions. Gastroenterology 155(5): 1372-1382.
Shahamat, M., Mai, U.E.H., Paszko-Kolva, C., Yamamoto, H. \& Colwell, R.R. 1991. Evaluation of liquid media for growth of Helicobacter pylori. Journal of Clinical Microbiology 29: 2835-2837.

Sonwjaya, K., Spandana, U., Manjula, R.R., Havilah, E.S., Sravani, T. \& Rao, G.S.N. 2016. Wound healing activity and anti-ulcer activity of ethanolic extract of peels of Annas Comosus. European Journal of Pharmaceutical and Medical Research 3(3): 417-422.

Tombola, F., Campello, S., De Luca, L., Ruggiero, P., Del Giudice, G., Papini, E. \& Zoratti, M. 2003. Plant polyphenols inhibit vaca, a toxin secreted by the gastric pathogen Helicobacter pylori. FEBS Letters 543: 184-189.

Werawatganon, D. 2014. Simple animal model of Helicobacter pylori infection. World Journal of Gastroenterology 20(21): 6420-6424.

Xia, H.X., English, L., Keane, C.T. \& O’Morain, C.A. 1993. Enhanced cultivation of Helicobacter pylori in liquid media. Journal of Clinical Pathology 46: 750-753.

Xu, J., Czinn, S.J. \& Blanchard, T.G. 2010. Maintenance of Helicobacter pylori cultures in agar stabs. Helicobacter 15(5): 477-480.

Nur Nadiana Adnan, Endang Kumolosasi*, Norazrina Azmi, Noor Safwah Damanhuri \& Fhataheya Buang

Drug and Herbal Research Centre

Faculty of Pharmacy

Universiti Kebangsaan Malaysia

50300 Kuala Lumpur, Federal Territory

Malaysia

Marhanis Salihah Omar

The Center of Quality Management of Medicine

Faculty of Pharmacy

Universiti Kebangsaan Malaysia

50300 Kuala Lumpur, Federal Territory

Malaysia

Corresponding author; email: e_kumolosasi@ukm.edu.my

Received: 26 November 2019

Accepted: 16 May 2020 